\title{
Corrosion Study of Steel API 5A, 5L and AISI 1080, 1020 in Drill-Mud Environment of Iranian Hydrocarbon Fields
}

\author{
M. Farzam, ${ }^{1}$ P. Baghery, ${ }^{1}$ and H. R. Mardan Dezfully ${ }^{2}$ \\ ${ }^{1}$ Petroleum University of Technology, Abadan, Iran \\ ${ }^{2}$ National Iranian Drilling Company, Ahwaz, Iran
}

Correspondence should be addressed to M. Farzam, farzam@put.ac.ir

Received 20 April 2011; Accepted 7 June 2011

Academic Editor: T. Laurila

Copyright (C 2011 M. Farzam et al. This is an open access article distributed under the Creative Commons Attribution License, which permits unrestricted use, distribution, and reproduction in any medium, provided the original work is properly cited.

\begin{abstract}
API 5A and 5L (grades J55, H40, N80, and K55) are used in making drill pipe and well casing. In this paper after studying the rheological and chemical properties of the mud, the effective corrosion parameters were reviewed and studied. The drill pipe corrosion management, with reference to NACE PRO 502-2002 was made and showed that for 50 drilling rigs 120 million dollars is to be spent in 21 years for corrosion damage. Potentiodynamic polarization tests were made to study the drill-pipe (API 5A), well casing (API 5L), a connecting tube (AISI 1020), and drill cable (AISI 1080) corrosion behavior in different pH and mud chemistry; following these tests, the pitting potential at which wash-out of drill pipe occurs was determined.
\end{abstract}

\section{Introduction}

Drill-mud is either water or oil based; the water-based mud which mostly used for oil field drilling is consisting of two phases: liquid phase and solid phase. Its liquid phase is made of sweet, salty (brine), soft, or hard water, and its solid phase is made of clay; usually Bentonite. Additives to the mud are either to control its rheology, mechanical properties (viscosity, gel strength, etc.), or $\mathrm{pH}$ and other chemical parameters. The main duties of mud are [1]

(1) removing cuttings from the well bottom,

(2) cooling the drill bit and the pipe,

(3) lubricating the drill bit and the pipe,

(4) holding the well's wall in place,

(5) controlling the pressure,

(6) suspension of the solids,

(7) enduring some weight of the pipe and the bit,

(8) giving down-hole information.

While the water-based mud results in well equipment corrosion, the oil-based mud is believed to have little corrosion problem [1].
During the drilling operation, $\mathrm{O}_{2}, \mathrm{H}_{2} \mathrm{~S}, \mathrm{CO}_{2}$, and other chemicals diffuse and contaminate the mud. Oxygen enters the mud from the air; $\mathrm{H}_{2} \mathrm{~S}$ contaminates the mud from the reservoir, SRB (Sulfate Reducing Bacteria), and the breakup of the additives.

$\mathrm{H}_{2} \mathrm{~S}$ will promote pitting corrosion and also may cause hydrogen degradation:

$$
\mathrm{H}_{2} \mathrm{~S}+\mathrm{Fe} \longrightarrow \mathrm{FeS}+\mathrm{H}_{2}
$$

The pitting corrosion acts as stress concentration to lead to wash-out, while $H$ embrittlement will promote corrosion fatigue. sion:

$\mathrm{H}_{2} \mathrm{CO}_{3}$ from reservoir will also induce uniform corro-

$$
\begin{gathered}
\mathrm{CO}_{2}+\mathrm{H}_{2} \mathrm{O} \longrightarrow \mathrm{H}_{2} \mathrm{CO}_{3} \\
\mathrm{H}_{2} \mathrm{CO}_{3}+\mathrm{Fe} \longrightarrow \mathrm{FeCO}_{3}+\mathrm{H}_{2}
\end{gathered}
$$

Temperature and pressure increasing with depth of drilling operation will accelerate uniform corrosion and the extent of wash-out. Cleanliness of the pipe surface from oxides and scratches is also important; these can also promote pitting corrosion. Figures 1(a), 1(b), and 1(c) shows pitting of drill pipe, at the internal and the external surfaces. 


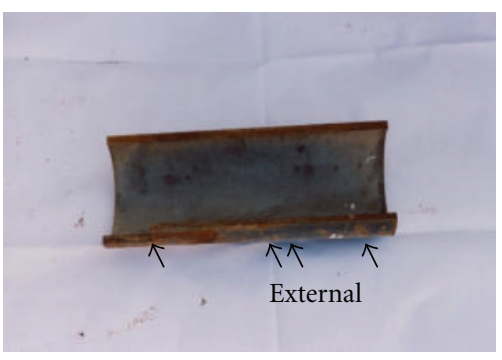

(a)

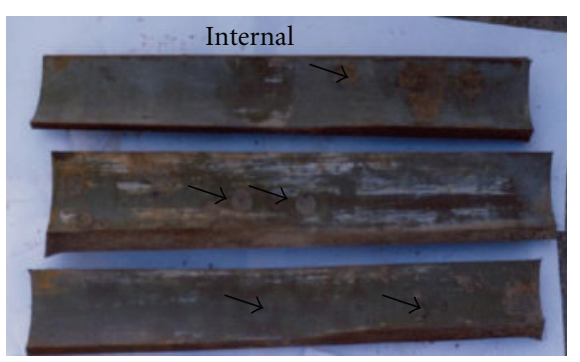

(b)

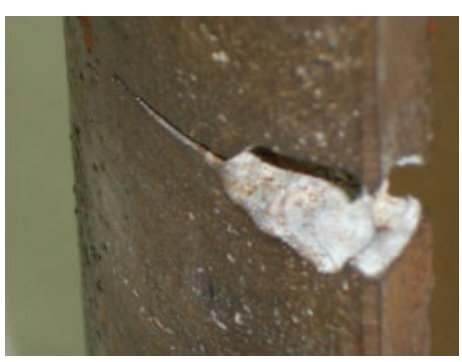

(c)

FIgURE 1: (a): External surface of the drill-pipe; pitted. (b): Internal surface of the drill-pipe; pitted. (c): Pits leading to wash-out; a fully developed fracture.

Such pits can initiate fatigue and stress corrosion cracks; the applied loads (residual and external) can accelerate the crack growth rate. The drilling operation, rotation speed, reservoirs conditions, the drill string weights, and drilling angle are all effective. Any unwarranted bending will accelerate such failure, leading to wash-out. It is expected that electrochemically the outside of the drill pipe will act anodic with respect to its inside, also when an old pipe is connected to a new pipe it will act anodic with respect to the old pipe [1].

Such failures have been reported previously $[1,2]$. National Association of Corrosion Engineers (NACE) survey [3] classifies oil and gas equipments corrosion into four categories: sweet corrosion in the presence of $\mathrm{CO}_{2}$, sour corrosion in the presence of $\mathrm{H}_{2} \mathrm{~S}$, oxygen corrosion due to local air and the surrounding atmosphere, and finally electrochemical corrosion due to the effect of various polarizations, activation, concentration, and resistance.

Pipe corrosion management model according to NACE PRO 502-2002 [4] was made. Results of periodical engineering inspection are circulated and number of drill pipe failures; wash-out, are counted. Thus for a period of time costs are evaluated. The cost of 20000 feet drill pipe is 60000 $\$$, each pipe has a life 7 years in average; therefore, for a single rig in 21 years the drill pipe cost of wash-out failure is 1.8 million dollars. Adding a cost of $3000 \$$ for technical inspection and dead time, the failure cost measures up to 2.4 million dollars; thus for 50 National Iranian Drilling company (N.I.D.C.) drill rigs the wash-out damage cost amounts to 120 million dollars.

\section{Experimental Procedure}

2.1. Sample Preparation. Four corroded components are selected to investigation of corrosion behavior in different corrosive environments.

(1) Drilling pipe (API 5A), see Figure 1.

(2) Well casing (API 5L), see Figure 2.

(3) Drill cable (AISI 1080), see Figure 3.

(4) Connection tube (AISI 1020), see Figure 4.

At first step, the specimens were cut by means of cutter, and then rough ground to reach the proper size. The rough grinding is continued until the surface is flat and free of nicks,

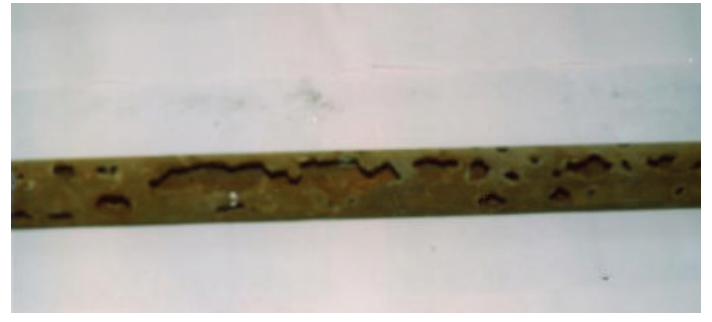

Figure 2: A fully pitted casing tube.

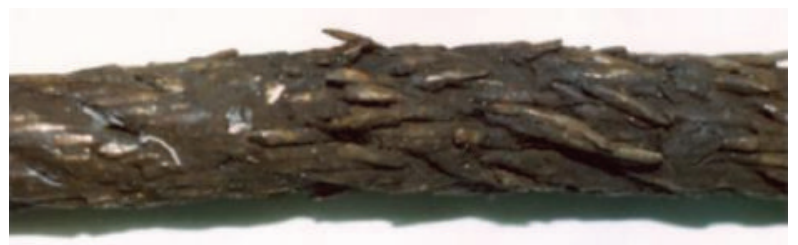

FIGURe 3: Drill cable (sample 3).

burrs, and so forth, and all scratches due to the cutoff wheel are no longer visible.

The copper wires with resistant cover are connected by silver paste to one side of each specimen and then the specimens were mounted by resin until an exposure surface to corrosive media excluded from mount. The area of surface calculated then surface wet ground with emery paper up to 800 grit. The substrates were ultrasonically cleaned in acetone for $10 \mathrm{~min}$ and finally washed with distilled water before potentiodynamic polarization tests.

2.2. Potentiodynamic Polarization. According to ASTM G594 [5], potentiodynamic polarization measurements were carried out in an open to air conventional three electrode cell which illustrated in Figure 5. The cell contains $500 \mathrm{~mL}$ of electrolyte. Measurements were performed in $0.1,1 \mathrm{M}$ $\mathrm{HCl}, 0.1,1 \mathrm{M} \mathrm{H}_{2} \mathrm{SO}_{4}, 0.1,1 \mathrm{M} \mathrm{NaOH}$ solutions, and five different kinds of mud at the temperature of $25 \pm 1^{\circ} \mathrm{C}$. The mounted specimens were used as working electrode. Platinum electrode and $\mathrm{Ag} / \mathrm{AgCl}$ electrode were used as counter electrode and the reference electrode. The working electrode was degreased by immersion in acetone, rinsed 


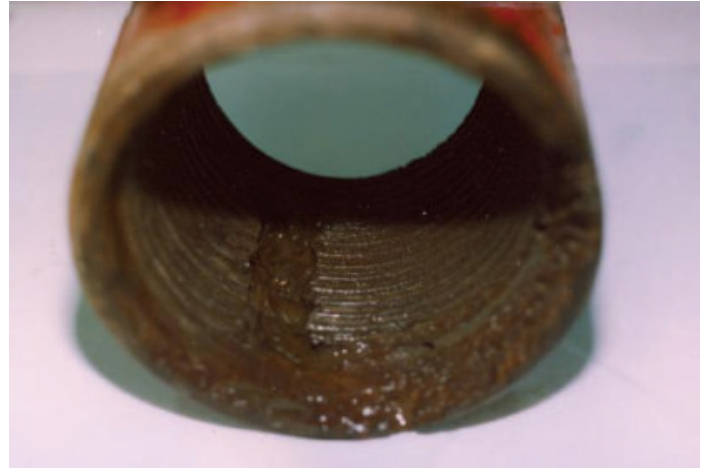

FIgure 4: Connecting tube (sample 4).

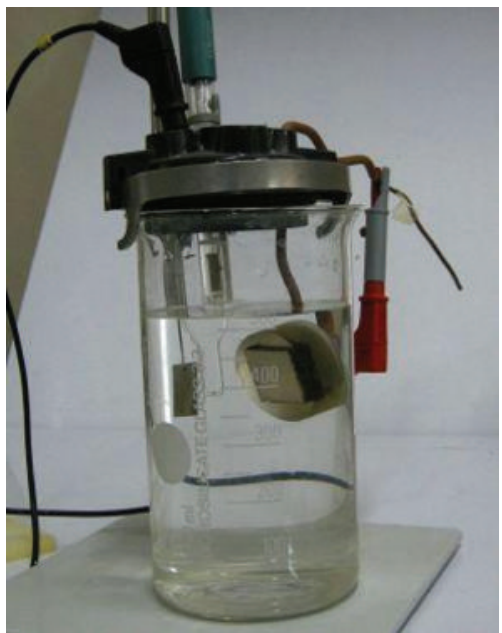

FIGURE 5: Conventional three-electrode cell used for electrochemical experiments.

with water, and immediately inserted whilst wet in the cell. Polarization studies were conducted using computer controlled potentiostat device which is shown in Figure 6. The open circuit potential (OCP) was measured after immersion, and when OCP reaches to stable condition the polarization measurements were done. Potentiodynamic measurements were performed at a potential scanning rate of $0.5 \mathrm{mV} / \mathrm{s}$. The corrosion potential $\left(E_{\text {corr }}\right)$ and corrosion current density $\left(i_{\text {corr }}\right)$ were calculated from the intersection of the cathodic and anodic Tafel curves using the Tafel extrapolation method.

2.3. Mud Preparation. Five different kinds of mud were made; the base mud was made of $14 \mathrm{~g}$ Bentonite in $350 \mathrm{cc}$ fresh water

Mud 1; $0.5 \mathrm{~g}$ lime was added to the base mud.

Mud 2: $1 \mathrm{~g}$ caustic soda was added to the base mud.

Mud 3: was only the base mud.

Mud 4: was the packer fluid.

Mud 5: $57.06 \mathrm{~g}$ salt was added to the base mud.

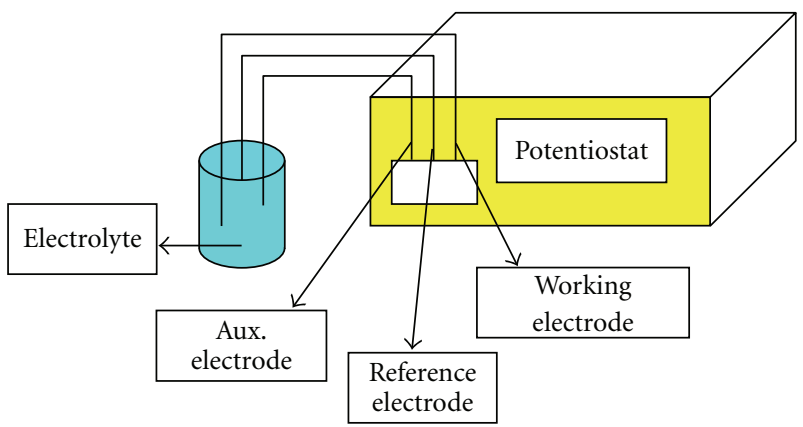

(a)

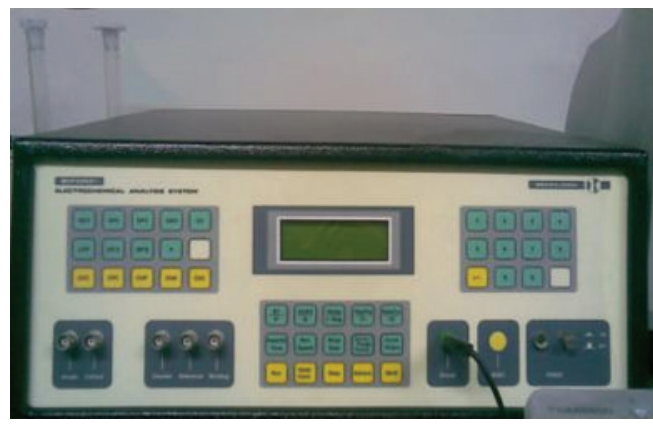

(b)

Figure 6: (a) the potentiostat circuit and (b) the potentiostat hardware.

Table 1 shows the mud properties such as viscosity, gel strength, weight, and $\mathrm{pH}$.

\section{Experimental Results}

3.1. Chemical Composition and Microstructure. Table 2 demonstrates the chemical composition of a few API grades available to be selected by the industry.

The metallography of the drill pipe material showed the microstructure to be tempered martensite; as seen in Figure 7, it is believed that such a structure is more resistance to stress corrosion cracking.

The composition and the metallography of the casing tube are in accordance with the API similar to that of the drill pipe used by National Iranian Drilling Company.

3.2. Potentiodynamic Polarization. About 100 separate polarization tests were conducted, and the results are tabulated in Tables 3, 4, 5, and 6 .

Figure 8 shows a sample of potentiodynamic polarization curves. Table 3 shows the corrosion potential and current and the passivation behavior. The free corrosion potential and free corrosion current were automatically given by the computer controlled apparatus. Epit is determined from polarization curves. Pits occur at if the current increases dramatically in the test.

The potentiodynamic tests were also conducted by imposing the reverse cycle (called path 2, note the normal curve was path 1). Similar tests were conducted for the casing 


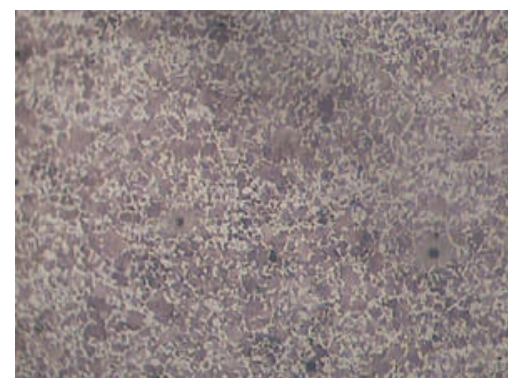

(a)

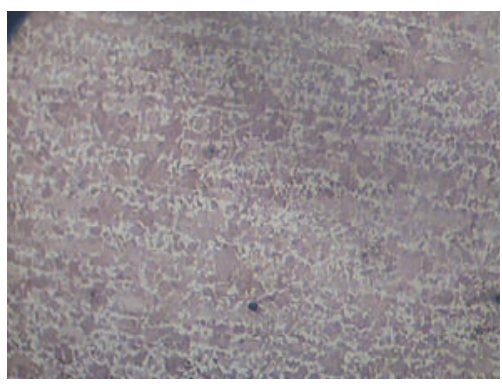

(b)

Figure 7: (a) Transverse section; tempered martensite (200x). (b) Longitudinal section; tempered martensite (200x).

TABLE 1: Drill-mud properties: viscosity, gel strength, weight, $\mathrm{pH}$, and temperature.

\begin{tabular}{lccccccccccc}
\hline Mud & $\theta_{600}$ & $\theta_{300}$ & $\theta_{200}$ & $\theta_{100}$ & $\theta_{6}$ & $\theta_{3}$ & $\mathrm{Gel}_{1}$ & $\mathrm{Gel}_{2}$ & $\mathrm{MW}$ & $\mathrm{pH}$ & $\mathrm{T}{ }^{\circ} \mathrm{C}$ \\
\hline 1 & 32 & 26 & 23.5 & 21.0 & 11.5 & 10.5 & 10 & 11 & 8.45 & 12.85 \\
2 & 21 & 17 & 14.5 & 12.5 & 9 & 8.5 & 13 & 19 & 8.50 & 11.12 & 25 \\
3 & 15 & 12 & 10 & 8.5 & 6.5 & 5.5 & 8 & 9 & 8.45 & 7.30 & 25 \\
4 & - & - & - & - & - & - & - & - & 75 & 5 & 25 \\
5 & 6 & 5 & 4 & 3.5 & 2 & 1.5 & 2 & 3 & 9.25 & 5.5 & 25 \\
\hline
\end{tabular}

TABLE 2: Chemical composition of drill pipe and casing.

\begin{tabular}{|c|c|c|c|c|c|c|c|c|c|c|c|c|c|}
\hline Steel & $\mathrm{C}$ & $\mathrm{Mn}$ & $\mathrm{Si}$ & $\mathrm{P}$ & $S$ & $\mathrm{Cr}$ & Mo & $\mathrm{Nb}$ & $\mathrm{V}$ & $\mathrm{Ti}$ & $\mathrm{Al}$ & B & $\mathrm{Fe}$ \\
\hline API 5L-X46 & $0.3 \max$ & $1.3 \max$ & - & $0.04 \max$ & $0.05 \max$ & - & - & - & - & - & - & - & balance \\
\hline API 5L-X60 & $0.26 \max$ & $1.35 \max$ & - & $0.04 \max$ & $0.05 \max$ & - & - & $0.05 \mathrm{~min}$ & $0.02 \mathrm{~min}$ & $0.03 \mathrm{~min}$ & - & - & balance \\
\hline $\begin{array}{l}\text { API 5L, Grade } \\
\text { X52 }\end{array}$ & $0.21 \max$ & 0.9 & 0.26 & $0.015 \max$ & $0.05 \max$ & - & - & - & 0.09 & - & 0.03 & - & balance \\
\hline $\begin{array}{l}\text { API 5A, Grade } \\
\text { K55 }\end{array}$ & $0.45 \max$ & 1.3 & 0.26 & $0.015 \max$ & $0.015 \max$ & - & - & - & - & - & $10^{-4}$ & - & balance \\
\hline $\begin{array}{l}\text { API 5AX, Grade } \\
\text { N-80 }\end{array}$ & $0.28 \max$ & 1.48 & 0.26 & $0.015 \max$ & $0.015 \max$ & 0.2 & 0.1 & - & - & - & 0.007 & - & balance \\
\hline $\begin{array}{l}\text { API 5AX, Grade } \\
\text { P-110 }\end{array}$ & $0.28 \max$ & 1.48 & 0.26 & $0.015 \max$ & $0.015 \max$ & 0.22 & 0.23 & - & - & - & 0.007 & - & balance \\
\hline $\begin{array}{l}\text { API } 5 \text { AC, Grade } \\
\text { C-90 }\end{array}$ & $0.29 \max$ & 0.5 & 0.26 & $0.015 \max$ & $0.015 \max$ & 1.08 & 0.33 & - & 0.03 & - & - & $10^{-3}$ & balance \\
\hline API 5L, Grade A & $0.17 \max$ & 0.5 & - & 0.02 & 0.02 & - & - & - & - & - & - & - & balance \\
\hline $\begin{array}{l}\text { API 5L, Grade } \\
\text { X60 }\end{array}$ & $0.05 \max$ & 1.11 & 0.01 & 0.007 & 0.006 & - & - & 0.045 & - & - & 0.045 & - & balance \\
\hline
\end{tabular}

TABLE 3: The potentiodynamic results of drill pipe (sample 1); path 1: anodic-cathodic, path 2: reverse scan. Sample 1: Drill Pipe.

\begin{tabular}{|c|c|c|c|c|}
\hline Media & $E_{\text {corr }} \mathrm{V}$ (path 1) & $E_{\text {corr }} \mathrm{V}$ (path 2) & $I_{\text {corr }} \mathrm{mA} / \mathrm{cm}^{2}$ & Passivation \\
\hline HCL $0.1 \mathrm{M}$ & -0.6 & -0.51 & 3500 & - \\
\hline $\mathrm{HCl} 1 \mathrm{M}$ & -.048 & -0.46 & 3600 & - \\
\hline $\mathrm{H}_{2} \mathrm{SO}_{4} 0.1 \mathrm{M}$ & -0.46 & -0.49 & 3400 & After $1.5 \mathrm{~V}$ \\
\hline $\mathrm{H}_{2} \mathrm{SO}_{4} 1 \mathrm{M}$ & -0.43 & -0.45 & 3500 & - \\
\hline $\mathrm{NaOH} 0.1 \mathrm{M}$ & -0.83 & -0.38 & 900 & -0.7 to 0.5 \\
\hline $\mathrm{NaOH} 1 \mathrm{M}$ & -0.91 & -0.29 & 900 & -0.8 to 0.4 \\
\hline Mud 1 & -0.82 & -0.56 & 200 & -0.6 to -0.1 \\
\hline Mud 2 & -0.61 & -0.52 & 350 & - \\
\hline Mud 3 & -0.64 & - & 150 & After 0.4 \\
\hline Mud 4 & -0.7 & -0.58 & 2500 & - \\
\hline
\end{tabular}


TABle 4: Potentiodynamic results of tube casing (sample 2); path 1: anodic-cathodic, path2: reverse scan. Sample 2: Tube Casing.

\begin{tabular}{|c|c|c|c|c|}
\hline Media & $E_{\text {corr }} \mathrm{V}$ (path 1) & $E_{\text {corr }} \mathrm{V}$ (path 2) & $I_{\text {corr }} \mathrm{mA} / \mathrm{cm}^{2}$ & Passivation \\
\hline HCL $0.1 \mathrm{M}$ & -0.51 & -0.53 & 2200 & - \\
\hline $\mathrm{HCl} 1 \mathrm{M}$ & -0.5 & -0.5 & 2200 & - \\
\hline $\mathrm{H}_{2} \mathrm{SO}_{4} 0.1 \mathrm{M}$ & -0.55 & -0.5 & 2000 & After $1.5 \mathrm{~V}$ \\
\hline $\mathrm{H}_{2} \mathrm{SO}_{4} 1 \mathrm{M}$ & -0.47 & -0.49 & 2300 & - \\
\hline $\mathrm{NaOH} 0.1 \mathrm{M}$ & -0.78 & -0.31 & 4000 & -0.6 to $0.5 \mathrm{~V}$ \\
\hline $\mathrm{NaOH} 1 \mathrm{M}$ & -0.83 & -0.33 & 900 & -0.7 to $0.9 \mathrm{~V}$ \\
\hline Mud 1 & -0.68 & -0.6 & 600 & Narrow range \\
\hline Mud 2 & - & - & - & - \\
\hline Mud 3 & -0.88 & -0.64 & 600 & - \\
\hline Mud 4 & -0.7 & -0.58 & 2000 & - \\
\hline Mud 5 & -0.74 & -0.56 & 2000 & - \\
\hline
\end{tabular}

TABle 5: The potentiodynamic tests of drill cable (sample 2); path 1: anodic-cathodic, path2: reverse scan. Sample 3: Drill Cable.

\begin{tabular}{|c|c|c|c|c|}
\hline Media & $E_{\text {corr }} \mathrm{V}$ (path 1) & $E_{\text {corr }} \mathrm{V}$ (path 2) & $I_{\text {corr }} \mathrm{mA} / \mathrm{cm}^{2}$ & Passivation \\
\hline HCL $0.1 \mathrm{M}$ & -0.5 & -0.52 & 12000 & After 1.5 \\
\hline $\mathrm{HCl} 1 \mathrm{M}$ & -0.5 & -0.44 & 12100 & - \\
\hline $\mathrm{H}_{2} \mathrm{SO}_{4} 0.1 \mathrm{M}$ & -0.47 & -0.47 & 12000 & After 1.5 \\
\hline $\mathrm{H}_{2} \mathrm{SO}_{4} 1 \mathrm{M}$ & -0.44 & -0.42 & 12200 & - \\
\hline $\mathrm{NaOH} 0.1 \mathrm{M}$ & -0.89 & - & 100 & -0.7 to 0.5 \\
\hline $\mathrm{NaOH} 1 \mathrm{M}$ & - & - & app Zero & -1 to 0.5 \\
\hline
\end{tabular}

TABle 6: Potentiodynamic tests for connecting tube (sample 4); path 1: anodic-cathodic and path 2: reverse scan. Sample 4: connecting tube.

\begin{tabular}{|c|c|c|c|c|}
\hline Media & $E_{\text {corr }} \mathrm{V}$ (path 1) & $E_{\text {corr }} \mathrm{V}$ (path 2) & $I_{\text {corr }} \mathrm{mA} / \mathrm{cm}^{2}$ & Passivation \\
\hline HCL $0.1 \mathrm{M}$ & -0.51 & -0.48 & 3700 & - \\
\hline $\mathrm{HCl} 1 \mathrm{M}$ & -0.46 & -0.45 & 3800 & - \\
\hline $\mathrm{H}_{2} \mathrm{SO}_{4} 0.1 \mathrm{M}$ & -0.48 & -0.51 & 3800 & After 1.5 \\
\hline $\mathrm{H}_{2} \mathrm{SO}_{4} 1 \mathrm{M}$ & -0.43 & -0.45 & 3800 & - \\
\hline $\mathrm{NaOH} 0.1 \mathrm{M}$ & -0.85 & -0.35 & 500 & -0.7 to 0.5 \\
\hline $\mathrm{NaOH} 1 \mathrm{M}$ & -0.92 & -0.1 & 500 & -0.7 to 0 \\
\hline Mud 1 & -0.76 & -0.58 & 500 & -0.6 to 0 \\
\hline Mud 2 & -0.8 & -0.48 & 400 & - \\
\hline Mud 3 & -0.58 & -0.58 & 300 & - \\
\hline Mud 4 & -0.76 & -0.62 & 3700 & - \\
\hline Mud 5 & -0.78 & -0.58 & - & - \\
\hline
\end{tabular}

material (Table 4), drill cable (Table 5), and the connecting tube (Table 6).

Increasing $\mathrm{pH}$ caused a shift in Ecorr to a more negative values, and a reduction in current Icorr was observed. Caustic soda and mud 1 showed drill pipe passivation.

In this case, the increase in $\mathrm{pH}$ showed a tube casing decrease in voltage and current, just like that of drill pipe.

While a drill cable is not directly in contact with drill mud its electrochemical behavior is of importance. It was noted that increased $\mathrm{pH}$ reduced both the potential and current.
The connecting tube used in the mud circulating rig piping system showed a similar electrochemical behavior as in samples 1 and 2, with large passive region in mud 1 .

The number of polarization tests conducted was up to 94, and the data obtained were in line with that of Jones [6].

\section{Discussion}

The corrosion of steel grade API 5A and 5L used to make drill pipe and casing is affected by water, mud, and reservoir constituents. The mud had different chemical and rheologic 


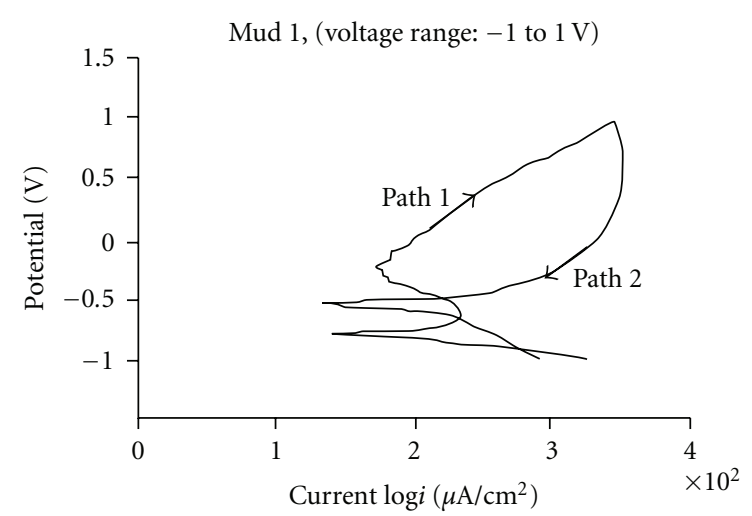

(a)

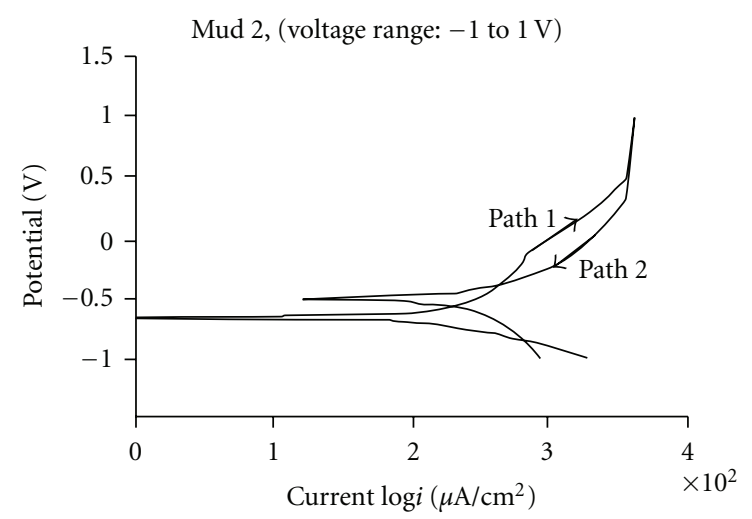

(b)

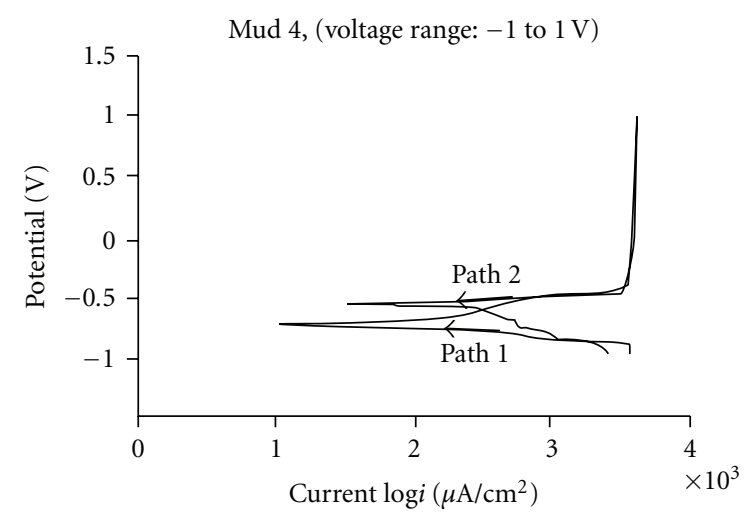

(c)

Figure 8: (a): Drill pipe (sample 1) tested in mud $1(\mathrm{pH}=12.85)$; the interaction of paths 1 and 2 is the Epit. (b): Drill pipe (sample 1) tested in mud $2(\mathrm{pH}=11.12)$; the interaction of paths 1 and 2 is the Epit. (c): Drill pipe (sample 1) tested in mud $4(\mathrm{pH}=5)$; the interaction of path 1 and 2 is the Epit.

properties (Table 1); the mud number 1 and 2 had higher $\mathrm{pH}$ than others; this was due to the presence of lime $\left(\mathrm{CaCO}_{3}\right)$ and caustic soda $(\mathrm{NaOH})$. Corrosion rate at higher $\mathrm{pH}$ is expected to be lower. One may expect a passive film and a hydro oxide film formation:

$$
\begin{gathered}
2 \mathrm{NaOH}+\mathrm{CO}_{2}+\mathrm{H}_{2} \mathrm{O} \longrightarrow 2 \mathrm{H}_{2} \mathrm{O}+\mathrm{Na}_{2} \mathrm{CO}_{3} \\
\mathrm{Ca}(\mathrm{OH})_{2}+\mathrm{CO}_{2} \longrightarrow 2 \mathrm{H}_{2} \mathrm{O}+\mathrm{CaCO}_{3}
\end{gathered}
$$

Caustic soda had a similar effect and corrosion retardation in the presence of sour gas:

$$
\begin{gathered}
\mathrm{H}_{2} \mathrm{~S}+\mathrm{NaOH} \longrightarrow \mathrm{NaHS}+\mathrm{H}_{2} \mathrm{O} \\
\mathrm{NaHS}+\mathrm{NaOH} \longrightarrow \mathrm{Na}_{2} \mathrm{~S}+\mathrm{H}_{2} \mathrm{O}
\end{gathered}
$$

Al-Awad et al. [7] doing a similar research but in Saudi Arabia agree with the above finding. Their experiments on API 5A grades $\mathrm{K}-55$ and $\mathrm{J}-55$ pipes showed that the effect of mud $\mathrm{pH}$ on the corrosion was detrimental. Increased corrosion in the dynamic state of mud flow and decreased corrosion rate both in dynamic and static flow obtained when $\mathrm{NaOH}$ was added. Mud number 3 had a near neutral $\mathrm{pH}$; it constituted only Bentonite. Mud number 4 and mud no. 5 had low $\mathrm{pH}$ thus may expect hydrogen reduction and no passivation; this was concluded experimentally. The European patent EP 1076113 [8] states that high performance phosphorus containing corrosion inhibitors may be used to retard corrosion in the drilling fluid system.

Visual inspection of the components; sample 1: drill pipe; Figure 1: and casing tube; Figure 2: drilling cable; Figure 3: connecting tube; Figure 4, showed that failure has taken place [1-3]. Drill pipe failure wash-out terminology may be used to describe its total fracture, and casing tube showed pitting which would lead to well collapse; drilling cable was hammered and cut while the connecting tube was eroded-corroded. The most important item of these samples is sample number 1 since its failure is costly both in direct and indirect operational costs. Looking closely at Figure 1, it is noted that the surface is heavily pitted and the size of the pits was in the range of 0.3 to $1.06 \mathrm{~mm}$. For pits to initiate electrochemically, pitting potential must be reached; since the composition of the drill mud is of almost uniform, one may expect material heterogeneity, inclusions, bandings, surface, and sub surface cavities and to be responsible for pit initiation. On the other hand deformation could also have effect. The passive film was present, and pitting potential at the conjunction of the reverse scan with its original path was obtained. The pitting potential differs in different mud compositions (Figures 8(b) and 8(c)); changing alloying composition (samples 2 and 4 ) affects the possible formation of passivation and the value of the pitting potential. Luo et al. [9] conducted similar research and found identical wash-out morphology and pit size. They also showed that at the final stages of fracture fatigue striations exist. Macdonald [10] concluded that besides some design shortcomings, fatigue, corrosion fatigue, overloading promoted by alternating axial loads, torsional and bending stresses, and mud chemistry were responsible for wash-out presence and drill pipe stresscorrosion fatigue failure. Acuña-González et al. [11] showed that the increment of $\% \mathrm{D}$ (Determinism) indicated that pitting current was predominant in the corrosion fatigue current oscillation.

Fatigue cycles due to the loading conditions mentioned above cause extrusions-intrusions leading to slip steps formations which may also be the source of pitting corrosion [12]. Some researchers have made theoretical approach into drill pipe fatigue failure $[13,14]$ using Lagrangian and Finite 
Element Dynamic Analysis to explain stick-slip, torsional, and vibrational oscillation effect on fatigue.

The extent of corrosion pit (wash-out) dissolving crack tip fatigue is a unique crack initiation and advance mechanism. It is better understood when combining fatigue data with electrochemical studies [15].

Data gathered from the dynamic polarization tests are presented in Table 3 (sample 1), Table 4 (sample 2), Table 5 (sample 3), and Table 6 (sample 4). It is noted that decreasing $\mathrm{pH}$ results in shifting potential and increasing current, and that passivation happened in mud 1 (lime plus Bentonite) and mud 2 (caustic soda plus Bentonite). Such passivation due to an increased $\mathrm{pH}$ is preferred in the field as corrosion will be retarded. Whitefield and Bennekom [15] experiments showed that as passivation prevailed current reduced and potential became more negative, on set of passivation is a proven stress-corrosion fatigue mechanism known as strainassisted active path [12].

By conducting reverse cycle dynamic polarization tests in mud 1 and mud 2 pitting potential at the breaking point with the passive region could be obtained. Once pit initiated could advance autocatalytically leading to reduced $\mathrm{pH}$ at the pit bottom; hydrogen degradation could lower the fatigue strength.

Tilted angle drilling operation, dog-leg, material upset, and change in section could lead to plastic deformation therefore increasing corrosion rate. Lu et al.'s [16] investigation on the erosion-corrosion of stainless steel drill pipe showed that surface deformation increased the rate of erosion-corrosion.

Standards pipe corrosion model was used to calculate the cost of wash-out [4]; it was concluded that for 50 rigs (belonging to National Iranian Oil Company) for a period of 21 years 120 million dollars must be spent for wash-out stress corrosion fatigue failure.

The author's many years of research suggests that material defaults are to be responsible for wash-out failure thus to improve rigs life material according to API standard requirements that must be used; API 5D for drill pipe, API spec 7 for drill stem, and API RP 7G for rigs optimum operating condition.

Changing the drill pipe material to duplex stainless steel was suggested by Bi et al. [17], they showed the polarizing potential of such steels was the reason for their increased service life.

External coating by $\mathrm{Cr}$ or $\mathrm{Zn}$ may also improve the drill pipes life [14]. Lastly as was mentioned previously, inhibitor addition is used to reduce corrosion rates $[1,8]$.

\section{Conclusions}

(1) Drill pipe failure was caused by wash-out which in turn was initiated by pitting corrosion.

(2) The pits were initiated at the outer surface of the pipe.

(3) The loading regime; a multiaxial fatigue was responsible for pits propagation.
(4) Polarization tests on drill pipe in different mud showed that $\mathrm{pH}$ had direct effect on corrosion and current.

(5) Passivation took place in basic drilling mud: Bentonite plus lime and Bentonite plus caustic soda.

(6) Reverse scan polarization test revealed the drill pipe's pitting potential in the passivating mud.

(7) Tube casing and the connecting tube polarization tests showed similar electrochemical behavior as that of drill pipe.

(8) As mud pH changed pitting potential changed; the high $\mathrm{pH}$ was the cause of passivation, where pitting initiated at Epit.

(9) Drill cable corrosion currents due to their inherent heavily deformed microstructure were higher than other samples.

(10) NACE pipe corrosion model used to calculate the cost of wash-out showed 120 million dollars cost in 21 years.

\section{Acknowledgments}

Hereby the authors wish to thank Petroleum University authorities and National Iranian Drilling Oil Company for their corporation and assistance.

\section{References}

[1] M. Farzam, "Research into causes of National Iranian Drilling Company's equipments and their preventions," Reports 1, 2 and 3, 2005 to 2007.

[2] A. Husain and A. Hasan, "A mysterious downhole corrosion failure in an oil well," in Proceedings of the 2nd Arabian Corrosion Conference on Industrial Corrosion and Corrosion Control Technology, p. 215, Kuwait Institute for Scientific Research, 1996.

[3] NACE, Corrosion of Oil Well Equipments, National Association of Corrosion Engineers, 1976.

[4] NACE, (National Association of Corrosion Engineers) PRO 502-2002.

[5] ASTM Designation G5-94, "Standard reference test method for making potentiostatic and potentiodynamic anodic polarization measurement," in Annual Book of ASTM Standards, ASTM International, Conshohocken, Pa, USA, 1999.

[6] D. A. Jones, Principles and Prevention of Corrosion, chapters 3 and 4, Macmillan Publishing Company, New York, NY, USA, 1992.

[7] M. N. J. Al-Awad, A. S. Dahab, and M. E. El-Dahshan, "Testing of drilling fluid formulated from tabuk formation clays," in Proceedings of the 2nd Arabian Corrosion Conference on Industrial Corrosion and Corrosion Control Technology, pp. 111-125, Kuwait Institute for Scientific Research, October, 1996.

[8] European Patent EP 1076113.

[9] F. Luo, C. Qin, and X. Wang, "Failure analysis of IEU drill pipe wash-out," International Journal of Fatigue, vol. 27, no. 10-12, pp. 1360-1365, 2005. 
[10] K. A. Macdonald, "Failure analysis of drill-string and bottom hole assembly components," Engineering Failure Analysis, vol. 1, no. 2, p. 91, 1994.

[11] N. Acuña-González, E. García-Ochoa, and J. GonzálezSánchez, "Assessment of the dynamics of corrosion fatigue crack initiation applying recurrence plots to the analysis of electrochemical noise data," International Journal of Fatigue, vol. 30, no. 7, pp. 1211-1219, 2008.

[12] M. Farzam, Corrosion and Corrosion Protection, Yadvareh Publishing Company, Tehran, Iran, 1999.

[13] Y. A. Khulief, F. A. Al-Sulaiman, and S. Bashmal, "Vibration analysis of drill-string with self exited stick-slip oscillation," Journal of Sound and Vibration, vol. 299, no. 3, pp. 540-558, 2007.

[14] S. Masaki, "Drill pipe failure prevention, corrosion protection with drill pipe surface coating and management of drill pipe using fatigue data base," Journal of Japans Association for Petroleum Technology, vol. 7, no. 5, p. 445, 2006.

[15] D. J. Whitefield and A. van Bennekom, "Abrasive wear properties of experimental metastable duplex stainless steels," Wear, vol. 196, no. 1-2, pp. 92-99, 1996.

[16] X. C. Lu, K. Shi, S. Z. Li, and X. X. Jiang, "Effects of surface deformation on corrosive wear of stainless steel in sulfuric acid solution," Wear, vol. 225-229, no. 1, pp. 537-543, 1999.

[17] H. Y. Bi, X. X. Jiang, and S. Z. Li, "The corrosive wear behavior of Cr-Mn-N series casting stainless steel," Wear, vol. 225-229, no. 2, pp. 1043-1049, 1999. 

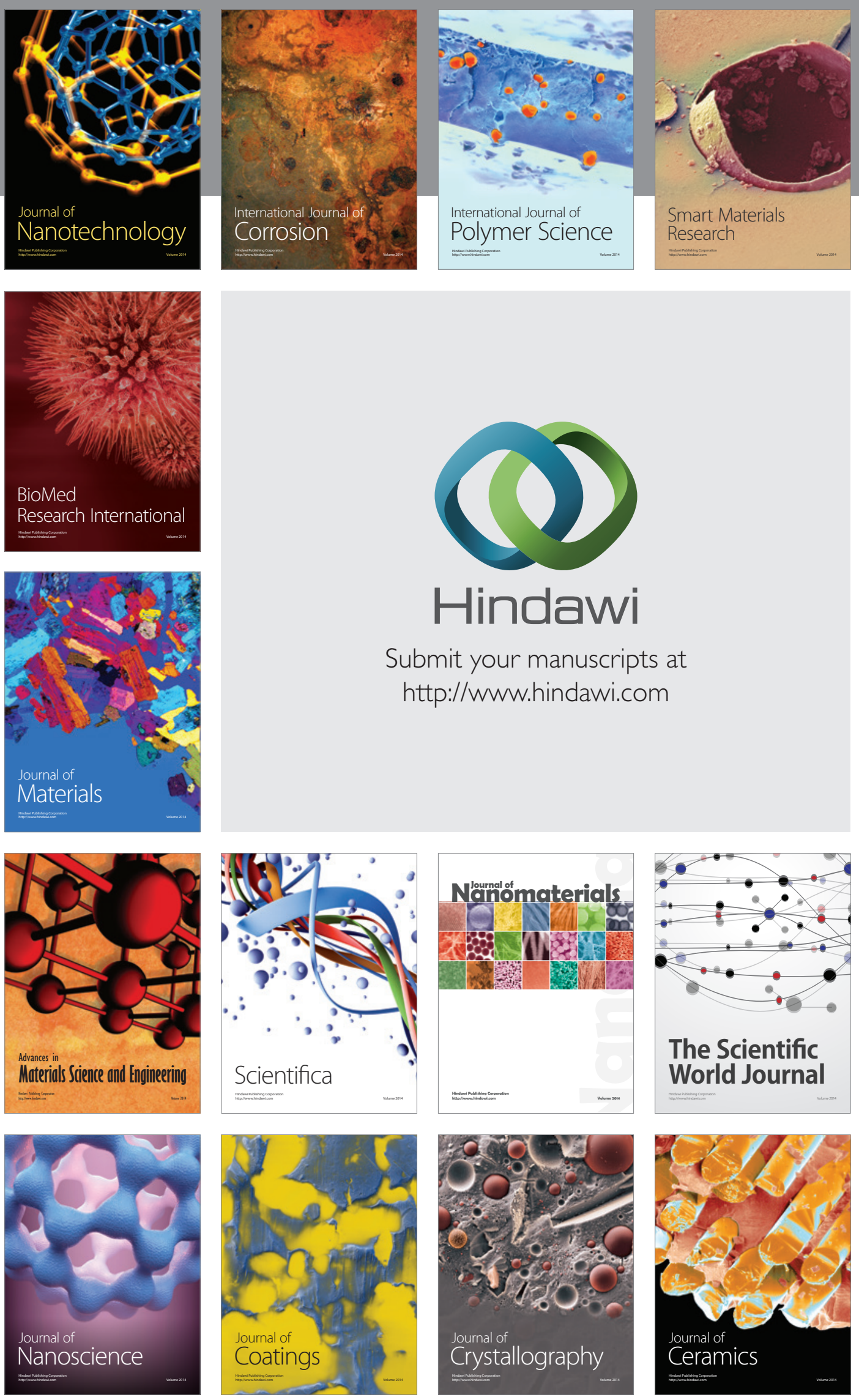

The Scientific World Journal

Submit your manuscripts at

http://www.hindawi.com

\section{World Journal}

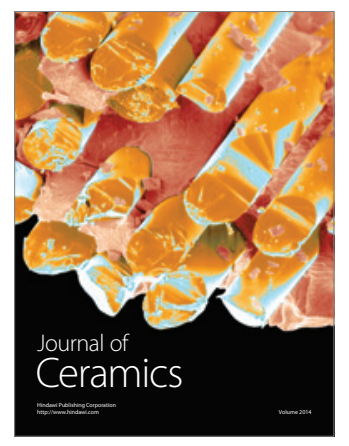

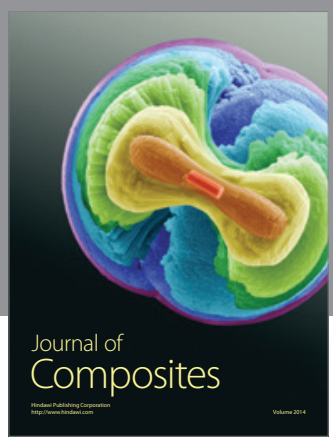
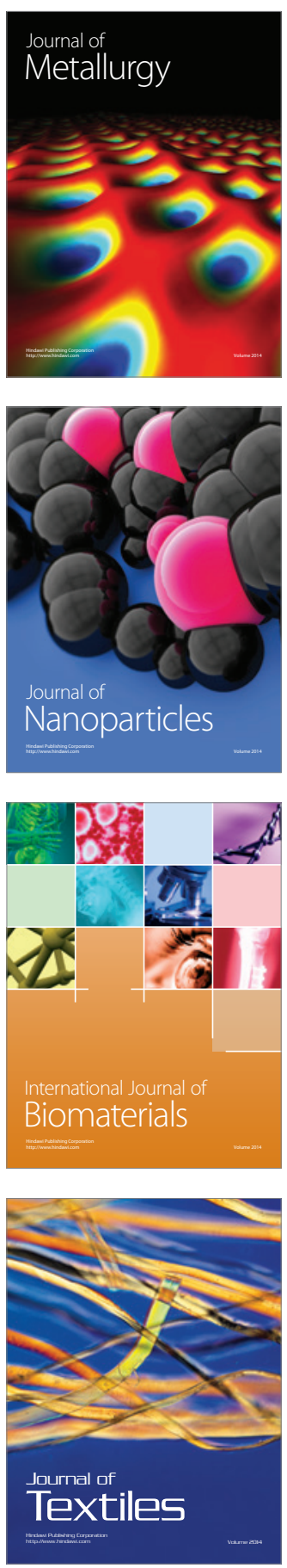